\title{
Si poisoning and promotion on the microstructure and mechanical properties of Al-Si-Mg cast alloys
}

\author{
Xixi Dong ${ }^{1}$ and Shouxun $\mathrm{Ji}^{1, *}$ \\ ${ }^{1}$ Brunel Centre for Advanced Solidification Technology (BAST), Brunel University London, Uxbridge, Middlesex UB8 3PH, UK
}

Received: 2 November 2017

Accepted: 10 January 2018

Published online:

12 February 2018

(C) The Author(s) 2018. This article is an open access publication

\begin{abstract}
Hypoeutectic $\mathrm{Al}-x \mathrm{Si}-0.45 \mathrm{Mg}(x=6.5,7.5,8.5,9.5)$ alloys were refined by Al5Ti1B containing $\mathrm{TiB}_{2}$ and $\mathrm{Al}$ Thi3B containing $\mathrm{TiB}_{2}$ and $\mathrm{AlB}_{2}$, respectively. With increasing $\mathrm{Si}$, Si poisoning on $\mathrm{TiB}_{2}$ results in the obvious coarsening of primary $\alpha$-Al in Al5Ti1B-refined alloys from $350 \pm 40$ to $400 \pm 50,475 \pm 50$ and $560 \pm 80 \mu \mathrm{m}$, and the competition between Si promotion on $\mathrm{AlB}_{2}$ and Si poisoning on $\mathrm{TiB}_{2}$ leads to the slight coarsening of primary $\alpha$-Al in Al3Ti3B-refined alloys from $215 \pm 30$ to $265 \pm 35,265 \pm 30$ and $315 \pm 25 \mu \mathrm{m}$. After T6 heat treatment, with increasing $\mathrm{Si}$, the yield strength (YS) of Al5Ti1B-refined alloys increases from $294 \pm 2$ to $299 \pm 2,304 \pm 1$ and $309 \pm 2 \mathrm{MPa}$, and the elongation first increases from $3.5 \pm 0.8$ to $4.5 \pm 1.0$ and $7.8 \pm 1.4 \%$, after decreases to $5.5 \pm 1.2 \%$, while the YS of the Al3Ti3B-refined alloys increases from $300 \pm 1$ to $305 \pm 2,312 \pm 1$ and $317 \pm 2 \mathrm{MPa}$, and the elongation increases from $6.1 \pm 1.1$ to $8.5 \pm 1.2,11.8 \pm 1.5$ and $12.1 \pm 1.6 \%$. The increase in the secondary phase and precipitation strengthening results in the increase in strength with increasing $\mathrm{Si}$. With increasing $\mathrm{Si}$, the decrease in porosity formation by decreasing solidification interval and increasing fluidity is superior to the increase in porosity formation by slightly coarsening grain size, which leads to the increase in ductility in the Al3Ti3B-refined alloys, while the competition between porosity decreasing and increasing factors leads to the inverted ' $\mathrm{V}$ 'shaped evolution of ductility in the Al5Ti1B-refined alloys.
\end{abstract}

\section{Introduction}

Al-Si-Mg cast alloys have been widely used for making high-integrity castings with a combination of good castability, low density, high-strength-toweight ratio, good corrosion resistance and low coefficient of thermal expansion, which are necessary for transport manufacturing to provide light- weighting components. Grain refinement has been proved as an important way to obtain fine primary $\alpha$ Al grains, which can improve the toughness, strength, formability and machinability [1-11].

The most widely used grain refiner in aluminium alloys over the past several decades is the Al5Ti1B master alloy with $\mathrm{TiB}_{2}$ particles and excess $\mathrm{Ti}$, which inoculates the melt with $\mathrm{TiB}_{2} / \mathrm{TiAl}_{3}$ particles as

Address correspondence to E-mail: shouxun.ji@brunel.ac.uk 
heterogeneous nuclei, and the sufficient free Ti solute in the melt can restrict the growth of primary $\alpha-\mathrm{Al}$ grains after nucleation. The exact mechanism of grain refinement under Al5Ti1B has been well demonstrated recently; the formation of a monolayer of (112) $\mathrm{Al}_{3} \mathrm{Ti}$ two-dimensional compound on the (0001) $\mathrm{TiB}_{2}$ surface can reduce the misfit between $\mathrm{TiB}_{2}$ and $\alpha-\mathrm{Al}$ from -4.2 to $0.09 \%$, which can efficiently enhance the nucleation potency of $\mathrm{TiB}_{2}$ particles for primary $\alpha$ $\mathrm{Al}$ grains [12]. The Al5Ti1B master alloy offers good performance in the casting of wrought alloys, but it is hard to meet the expectations in cast Al-Si alloys, especially with a content of Si higher than $3.5 \mathrm{wt} \%$ [13-15]. The reason is that $\mathrm{Si}$ in the melt reacts with $\mathrm{Ti}$ to form Ti-Si phases, which poison the $\mathrm{TiB}_{2}$ nucleation site [16, 17]. The poisoning mechanism of $\mathrm{Si}$ on the $\mathrm{TiB}_{2}$ nucleation sites has been verified by experiment recently, and $\mathrm{Al}-\mathrm{Si}-\mathrm{Ti}$ particles were observed on the prism face of $\mathrm{TiB}_{2}$ particles [18].

To reduce or avoid $\mathrm{Si}$ poisoning, one effective way is to introduce B into the Al-Si alloys, and it is often achieved by adding $\mathrm{Al}-\mathrm{B}$ master alloy, in which $\mathrm{AlB}_{2}$ resides as the source to supply $B$, into the melt. The use of Al-B master alloys for the grain refinement of Al-Si cast alloys dated back to 1980s, and the grain size was continually reduced even with increasing $\mathrm{Si}$ content [15]. $\mathrm{AlB}_{2}$ is the dominated particle in $\mathrm{Al}-\mathrm{B}$ master alloys and has a small misfit between $\alpha-\mathrm{Al}$, and it was expected that $\mathrm{AlB}_{2}$ could be a potent nucleating substrate for $\alpha$-Al [19]. However, a number of observations $[20,21]$ showed that $\mathrm{AlB}_{2}$ alone without Si cannot effectively refine $\alpha$-Al, indicating that the solute Si may interfere with $\mathrm{AlB}_{2}$ to enhance its nucleating potential. There is still lack of unambiguous understanding of the mechanism. Recently, it has been proposed that the creation of a layer of $\mathrm{SiB}_{6}$ at the interface between $\mathrm{AlB}_{2}$ and $\mathrm{Al}$ may reduce the crystallographic mismatch, which can significantly improve the nucleating potency of $\mathrm{AlB}_{2}$, and the enhanced grain refining efficiency can be mainly attributed to the enhanced heterogeneous nucleation of $\mathrm{AlB}_{2}$ caused by $\mathrm{Si}$ [22]. However, an amount of $\sim 0.12 \mathrm{wt} \% \mathrm{Ti}$ is usually present in commercial cast aluminium alloys for grain growth restriction. It was found that the commercial $\mathrm{Al}-\mathrm{Si}-\mathrm{Mg}$ cast alloys could not enjoy the outstanding grain refinement efficiency of Al-B master alloys, with the presence of $\mathrm{Ti}$, since the $\mathrm{AlB}_{2}$ particles are readily transformed to $\mathrm{TiB}_{2}$ particles and then suffering from the Si poisoning, and the grain refinement efficiency of Al-B master alloys is much similar to Al5Ti1B master alloy for commercial Al-Si-Mg cast alloys with Ti present [23].

For the grain refinement of commercial Al-Si-Mg cast alloys containing $\mathrm{Ti}$, one effective way is to reduce the $\mathrm{Ti}$ content and increase the $\mathrm{B}$ content in the Al-Ti-B master alloys, and A13Ti3B master alloy with $\mathrm{TiB}_{2}$ particles and excess $\mathrm{B}$ was found providing effective grain refinement [10, 11, 23, 24]. Al3Ti3B master alloy was reported containing $\mathrm{TiB}_{2}$ and $\mathrm{AlB}_{2}$ particles [10, 11, 23], and both of these particles could be potentially heterogeneous nucleation sites. The exact mechanism of grain refinement under Al3Ti3B is still quite unclear. On the one hand, $\mathrm{Si}$ poisons the heterogeneous nucleation of $\mathrm{TiB}_{2}$ particles; on the other hand, $\mathrm{Si}$ promotes the heterogeneous nucleation of $\mathrm{AlB}_{2}$ particles, so it is interesting to study the effect of $\mathrm{Si}$ poisoning and promotion on the grain refinement of $\mathrm{Al}-\mathrm{Si}-\mathrm{Mg}$ cast alloys under Al3Ti3B. Furthermore, seldom did research focus on $\mathrm{Si}$ poisoning and promotion on the mechanical properties of Al-Si-Mg cast alloys.

The objective of this paper is to study the multiple effects of $\mathrm{Si}$ on the microstructure and mechanical properties of hypoeutectic $\mathrm{Al}-\mathrm{Si}-\mathrm{Mg}$ cast alloys under different grain refiners, especially Si poisoning under Al5Ti1B and Si promotion under Al3Ti3B, to provide high-performance cast $\mathrm{Al}-\mathrm{Si}-\mathrm{Mg}$ alloys with high strength and high ductility and meet the increasing requirements in automotive industry.

\section{Experimental}

\section{Materials and melt preparation}

A serial of hypoeutectic $\mathrm{Al}-\mathrm{Si}-\mathrm{Mg}$ cast alloys with $0.45 \mathrm{wt} \% \mathrm{Mg}$ and different Si contents $(6.5,7.5,8.5$ and $9.5 \mathrm{wt} \%$ ) were prepared and melted in $12-\mathrm{kg}$ capacity clay-graphite crucibles separately using the electric resistance furnace, and the detail compositions of the investigated alloys were measured by inductively coupled plasma atomic emission spectroscopy (ICP-AES) and are listed in Table 1. During melting, the temperature of the furnace was controlled at $750{ }^{\circ} \mathrm{C}$. After $1 \mathrm{~h}$ of homogenisation, $\mathrm{Al}-$ $10 \mathrm{wt} \% \mathrm{Sr}$ master alloy was added into the melt to make the desired Sr content of 140 ppm for modification. The melt was subsequently degassed through injecting pure argon into the melt by using a rotary 
Table 1 Chemical compositions of experimental alloys analysed by ICP-AES (wt\%)

\begin{tabular}{llllllll}
\hline Alloy & $\mathrm{Si}$ & $\mathrm{Mg}$ & $\mathrm{Cu}$ & $\mathrm{Fe}$ & $\mathrm{Mn}$ & $\mathrm{Ti}$ & $\mathrm{Al}$ \\
\hline A1 (A16.5Si0.45Mg) & 6.53 & 0.45 & 0.002 & 0.11 & 0.06 & 0.124 & Bal. \\
A2 (A17.5Si0.45Mg) & 7.54 & 0.45 & 0.002 & 0.11 & 0.06 & 0.122 & Bal. \\
A3 (A18.5Si0.45Mg) & 8.53 & 0.45 & 0.002 & 0.11 & 0.06 & 0.123 & Bal. \\
A4 (A19.5Si0.45Mg) & 9.52 & 0.45 & 0.002 & 0.11 & 0.06 & 0.124 & Bal. \\
\hline
\end{tabular}

degassing impeller at a speed of $350 \mathrm{rpm}$ for $4 \mathrm{~min}$. After degassing, the melt was hold for $10 \mathrm{~min}$ for temperature recovery, followed by adding $0.2 \mathrm{wt} \%$ Al5Ti1B or $0.2 \mathrm{wt} \%$ Al3Ti3B for grain refinement.

\section{Casting process and heat treatment}

With the intention of casting tensile test bars, the prepared melt was poured at $720{ }^{\circ} \mathrm{C}$ into an ASTM B-108 permanent mould preheated at $460{ }^{\circ} \mathrm{C}$, as shown in Fig. 1a. Figure $1 \mathrm{~b}$ shows the gravity casting made by the permanent mould, and two round tensile test bars were made from each casting, as indicated by the dashed rectangle box in Fig. 1a. With the intention of testing the fluidity of the investigated alloys, the prepared melt was poured at $720^{\circ} \mathrm{C}$ into an ASTM standard spiral flow fluidity test mould preheated at $460{ }^{\circ} \mathrm{C}$. Three fluidity tests and three density tests were made for each alloy to give the average spiral flow length and average porosity percentage with error bar, respectively. The cast tensile test bars were subjected to T6 heat treatment, including solution treatment and artificial ageing. Solution treatment was carried out at $540{ }^{\circ} \mathrm{C}$ for $8 \mathrm{~h}$,

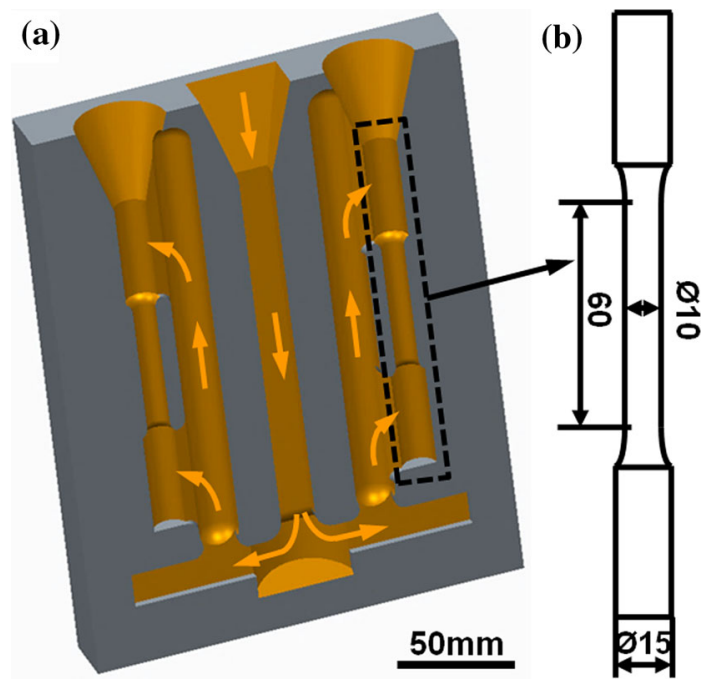

Figure 1 a Permanent mould made according to ASTM B-108, and $\mathbf{b}$ key dimensions of the gravity casting tensile test bar made by the mould. followed by immediate water quenching to room temperature. Ageing treatment was performed at $170{ }^{\circ} \mathrm{C}$ for $8 \mathrm{~h}$, followed by air cooling to room temperature.

\section{Microstructure characterisation and tensile tests}

The microstructure was examined using the Zeiss optical microscopy (OM), the Zeiss scanning electron microscope (SEM), the JEOL-2100 transmission electron microscopy (TEM) and the D8 X-ray diffraction (XRD) instrument. The specimens for OM and SEM analysis were prepared by the standard technique of grinding. Polarised OM observation of grain size was performed after anodised with Barker solution (97 vol\% $\mathrm{H}_{2} \mathrm{O}$ and $3 \mathrm{vol} \% \mathrm{HBF}_{4}$ ). SEM analysis was conducted after etching with the Keller solution (1 vol\% HF, $1.5 \mathrm{vol} \% \mathrm{HCl}, 2.5 \mathrm{vol} \% \mathrm{HNO}_{3}$ and $95 \mathrm{vol} \% \mathrm{H}_{2} \mathrm{O}$ ). Five polarised $\mathrm{OM}$ images with a magnification of 25 were counted to give each of the statistical average grain sizes with error bar. Thin specimens for TEM observation were prepared by standard electropolishing. The electrolytic solution was a mixture of nitric acid and methyl alcohol (2:8), used at -20 to $-30{ }^{\circ} \mathrm{C}$ and $20 \mathrm{~V}$. TEM operating at $200 \mathrm{kV}$ was used for bright-field imaging and highresolution TEM (HRTEM) imaging. XRD analysis was conducted from $2 \theta$ degrees $25^{\circ}-90^{\circ}$. Tensile tests were conducted at room temperature following the ASTM B557 standard using an Instron 5500 Testing System. Each tensile test data reported with error bar were based on the mechanical properties obtained from 6 to 8 samples.

\section{Results}

\section{As-cast microstructure}

Figure $2 \mathrm{a}-\mathrm{d}$ presents the polarised optical micrographs showing the grain size of primary $\alpha-\mathrm{Al}$ in the as-cast $\mathrm{Al}-x \mathrm{Si}-0.45 \mathrm{Mg}$ alloys with $6.5 \mathrm{wt} \% \quad \mathrm{Si}$, 

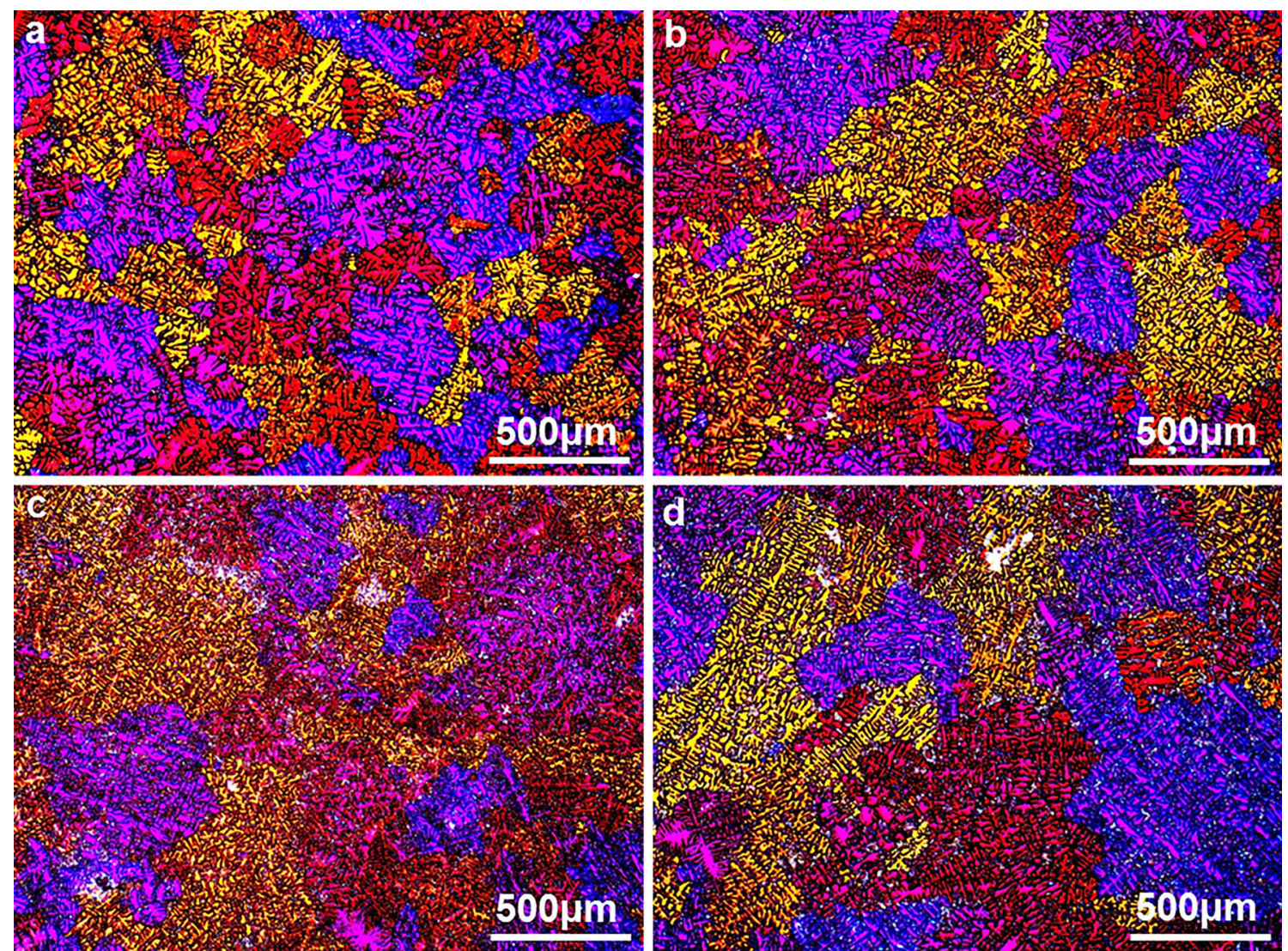

Figure 2 Polarised optical micrographs showing the grain size of primary $\alpha$-Al phase in the as-cast $\mathrm{Al}-x \mathrm{Si}-0.45 \mathrm{Mg}$ alloys refined by Al5Ti1B: a $6.5 \mathrm{wt} \% \mathrm{Si}, \mathbf{b} 7.5 \mathrm{wt} \% \mathrm{Si}$, c $8.5 \mathrm{wt} \% \mathrm{Si}$ and $\mathbf{d} 9.5 \mathrm{wt} \% \mathrm{Si}$.

$7.5 \mathrm{wt} \% \mathrm{Si}, 8.5 \mathrm{wt} \% \mathrm{Si}$ and $9.5 \mathrm{wt} \% \mathrm{Si}$, respectively, under the refinement of Al5Ti1B. When the Si content is increased to $7.5 \mathrm{wt} \%$, with the increase in $\mathrm{Si}$, the grain size of primary $\alpha$-Al phase is coarsened significantly, which indicates that the poisoning of $\mathrm{Si}$ on grain refinement is significant when the $\mathrm{Si}$ content is up to $7.5 \mathrm{wt} \%$, under the refinement of Al5Ti1B.

Figure $3 a-d$ presents the polarised optical micrographs showing the grain size of primary $\alpha$-Al phase in the as-cast $\mathrm{Al}-x \mathrm{Si}-0.45 \mathrm{Mg}$ alloys with $6.5 \mathrm{wt} \% \mathrm{Si}$, $7.5 \mathrm{wt} \% \mathrm{Si}, 8.5 \mathrm{wt} \% \mathrm{Si}$ and $9.5 \mathrm{wt} \% \mathrm{Si}$, separately, under the refinement of Al3Ti3B. The grain size of primary $\alpha$-Al phase in the $\mathrm{Al}-x \mathrm{Si}-0.45 \mathrm{Mg}$ alloys refined by Al3Ti3B is obviously smaller than that of the alloys refined by Al5Ti1B. With the increase in $\mathrm{Si}$, the coarsening of the primary $\alpha-\mathrm{Al}$ in the $\mathrm{Al}-x \mathrm{Si}-$ $0.45 \mathrm{Mg}$ alloys refined by Al3Ti3B is not obvious, which indicates that the poisoning of $\mathrm{Si}$ on the grain refinement of $\mathrm{Al}-x \mathrm{Si}-0.45 \mathrm{Mg}$ alloys is weak with the Si content up to $9.5 \mathrm{wt} \%$, under the refinement of Al3Ti3B.
Figure 4 shows the statistical average grain size of the primary $\alpha$-Al phase in the as-cast $\mathrm{Al}-\alpha \mathrm{Si}-0.45 \mathrm{Mg}$ $(x=6.5,7.5,8.5,9.5)$ alloys refined by Al5Ti1B and Al3Ti3B. Under the refinement of Al5Ti1B, the grain size of the primary $\alpha$-Al phase is $350 \pm 40 \mu \mathrm{m}$ with a Si content of $6.5 \mathrm{wt} \%$; with the increase in Si content to $7.5,8.5$ and $9.5 \mathrm{wt} \%$, the primary $\alpha-\mathrm{Al}$ phase is coarsened obviously to $400 \pm 50,475 \pm 50$ and $560 \pm 80 \mu \mathrm{m}$. The grain size of the primary $\alpha$-Al phase increases with the increase in $\mathrm{Si}$ content when refined by A15Ti1B; the grain size of the primary $\alpha-\mathrm{Al}$ phase is coarsened obviously when the Si content is up to $7.5 \mathrm{wt} \%$ and coarsened nearly linear after. Under the refinement of Al3Ti3B, the grain size of the primary $\alpha$-Al phase is fine as $215 \pm 30 \mu \mathrm{m}$ at $6.5 \mathrm{wt} \%$ $\mathrm{Si}$, and the grain size is increased to $265 \pm 35 \mu \mathrm{m}$ at $7.5 \mathrm{wt} \% \mathrm{Si}$, then the grain size is maintained at $265 \pm 30 \mu \mathrm{m}$ at $8.5 \mathrm{wt} \% \mathrm{Si}$, after the grain size is increased to $315 \pm 25 \mu \mathrm{m}$ at $9.5 \mathrm{wt} \% \mathrm{Si}$. The grain size of the primary $\alpha$-Al phase in the Al3Ti3B-refined alloy is significantly smaller than that of the Al5Ti1Brefined alloy. With the increase in $\mathrm{Si}$, the coarsening 

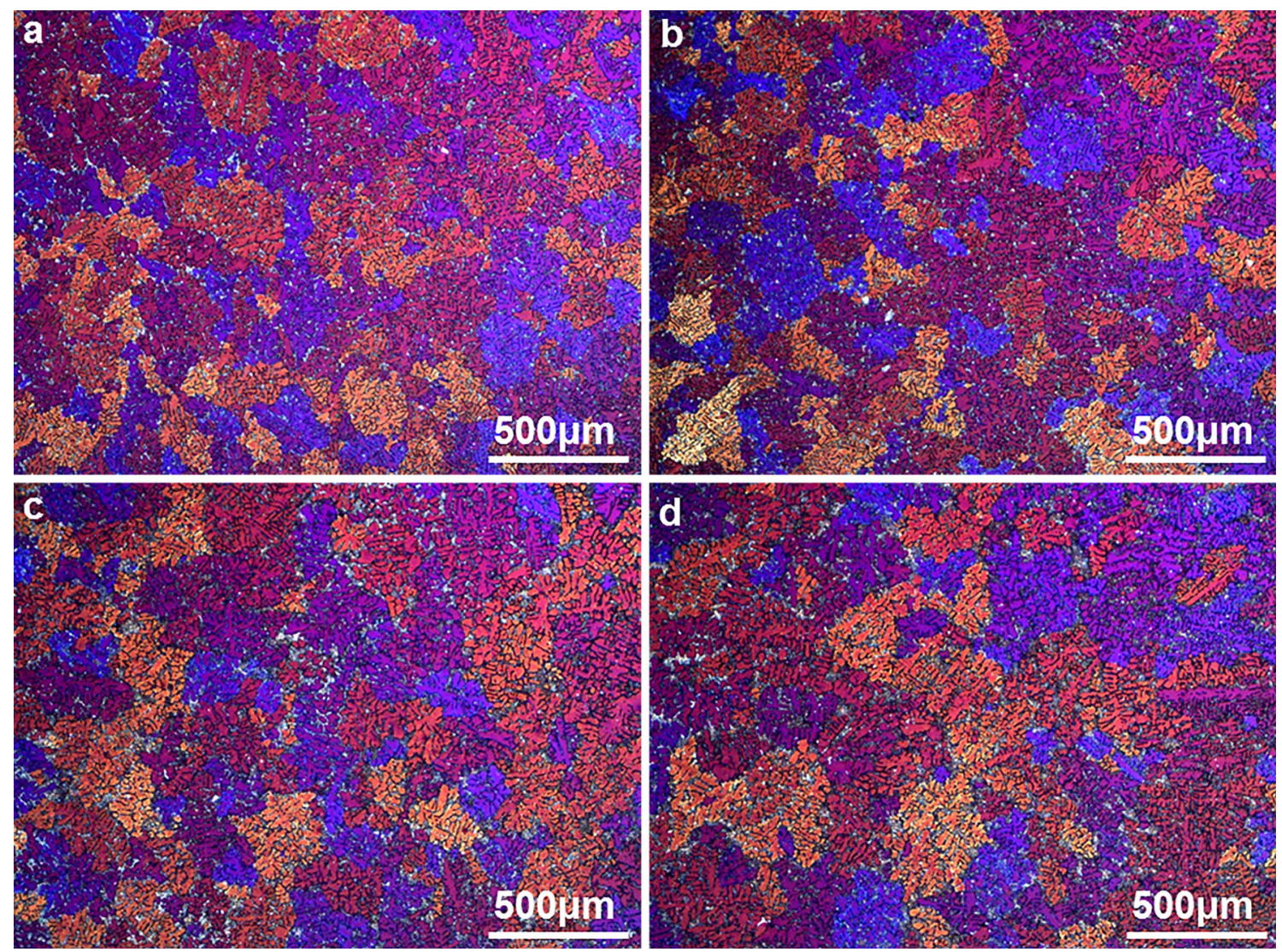

Figure 3 Polarised optical micrographs showing the grain size of primary $\alpha$-Al phase in the as-cast $\mathrm{Al}-x \mathrm{Si}-0.45 \mathrm{Mg}$ alloys refined by Al3Ti3B: a $6.5 \mathrm{wt} \% \mathrm{Si}, \mathbf{b} 7.5 \mathrm{wt} \% \mathrm{Si}, \mathbf{c} 8.5 \mathrm{wt} \% \mathrm{Si}$ and $\mathbf{d} 9.5 \mathrm{wt} \% \mathrm{Si}$.



Figure 4 Statistical average grain size of primary $\alpha$-Al phase in the as-cast $\mathrm{Al}-x \mathrm{Si}-0.45 \mathrm{Mg}(x=6.5,7.5,8.5,9.5)$ alloys refined by A15Ti1B and Al3Ti3B.

of the primary $\alpha$-Al phase in the Al3Ti3B-refined alloy is obviously slighter than that of the A15Ti1Brefined alloy.

Figure 5a-d shows the SEM morphology of the ascast hypoeutectic Al- $x \mathrm{Si}-0.45 \mathrm{Mg}$ alloys with $6.5 \mathrm{wt} \%$ Si, $7.5 \mathrm{wt} \% \mathrm{Si}, 8.5 \mathrm{wt} \% \mathrm{Si}$ and $9.5 \mathrm{wt} \% \mathrm{Si}$, respectively, under the refinement of Al5Ti1B master alloy.
Figure $5 \mathrm{e}-\mathrm{h}$ shows the SEM morphology of the ascast $\mathrm{Al}-x \mathrm{Si}-0.45 \mathrm{Mg}$ alloys with $6.5 \mathrm{wt} \% \mathrm{Si}, 7.5 \mathrm{wt} \%$ $\mathrm{Si}, 8.5 \mathrm{wt} \% \mathrm{Si}$ and $9.5 \mathrm{wt} \% \mathrm{Si}$, separately, under the refinement of Al3Ti3B master alloy. The insert in each figure shows the SEM morphology with high magnification. Primary $\alpha-\mathrm{Al}$ phase, eutectic Si phase and $\beta-\mathrm{Mg}_{2} \mathrm{Si}$ intermetallic phase coexist in the as-cast alloys refined by both Al5Ti1B and Al3Ti3B. $\beta-\mathrm{Mg}_{2} \mathrm{Si}$ phase is located in the Al-Si eutectic region. With the increase in $\mathrm{Si}$, the fraction of eutectic Si phase in the as-cast $\mathrm{Al}-x \mathrm{Si}-0.45 \mathrm{Mg}$ alloys increases, for the condition both refined by Al5Ti1B and Al3Ti3B.

\section{Microstructure after heat treatment}

Solution treatment can spheroidise the eutectic $\mathrm{Si}$ phase and dissolve intermetallic phases to form saturated solid solution [25]. Figure 6a-d shows the SEM morphology of the T6 heat-treated $\mathrm{Al}-x \mathrm{Si}-$ $0.45 \mathrm{Mg}$ alloys with $6.5 \mathrm{wt} \% \mathrm{Si}, 7.5 \mathrm{wt} \% \mathrm{Si}, 8.5 \mathrm{wt} \% \mathrm{Si}$ and $9.5 \mathrm{wt} \% \mathrm{Si}$, respectively, under the refinement of Al5Ti1B. Figure 6e-h shows the SEM morphology of 

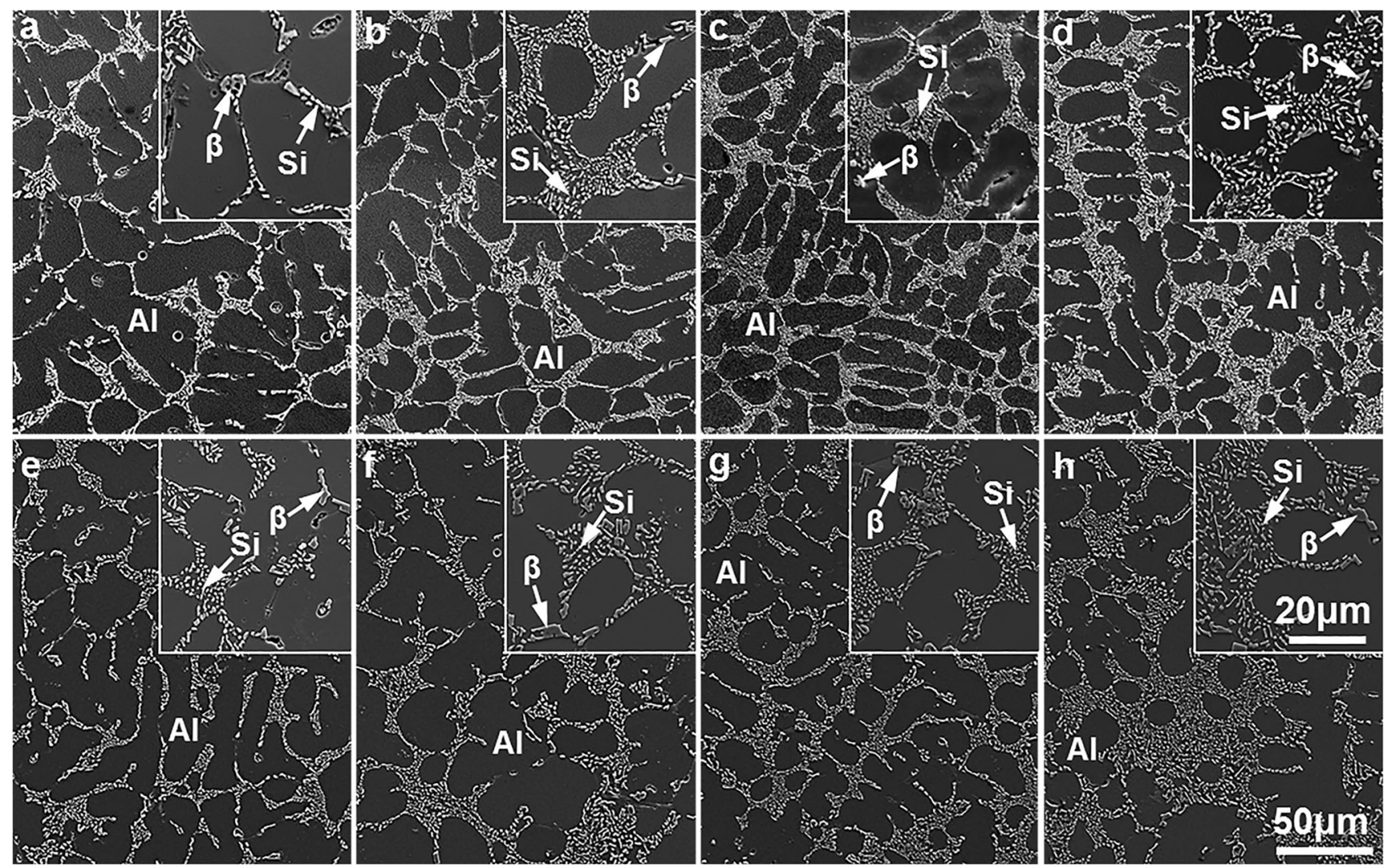

Figure 5 SEM micrographs showing the morphology of the as-cast $\mathrm{Al}-x \mathrm{Si}-0.45 \mathrm{Mg}$ alloys refined by: a-d Al5Ti1B and $\mathbf{e}-\mathbf{h} \mathrm{Al} 3 \mathrm{Ti3} \mathrm{B}$ with a, e $6.5 \mathrm{wt} \% \mathrm{Si}, \mathbf{b}, \mathbf{f} 7.5 \mathrm{wt} \% \mathrm{Si}, \mathbf{c}, \mathbf{g} 8.5 \mathrm{wt} \% \mathrm{Si}$ and $\mathbf{d}, \mathbf{h} 9.5 \mathrm{wt} \% \mathrm{Si}$.

the $\mathrm{T} 6$ heat-treated $\mathrm{Al}-x \mathrm{Si}-0.45 \mathrm{Mg}$ alloys with $6.5 \mathrm{wt} \% \mathrm{Si}, 7.5 \mathrm{wt} \% \mathrm{Si}, 8.5 \mathrm{wt} \% \mathrm{Si}$ and $9.5 \mathrm{wt} \% \mathrm{Si}$, separately, under the refinement of Al3Ti3B. The insert in each figure shows the SEM morphology with high magnification. Eutectic Si phase is spheroidal morphology, which indicates that the eutectic $\mathrm{Si}$ phase is spheroidised after T6 heat treatment. The spheroidised Si particles are fine, which are beneficial to ductility [26]. The morphology of the spheroidised $\mathrm{Si}$ particles in the Al5Ti1B- and Al3Ti3B-refined alloys is much similar. No $\beta-\mathrm{Mg}_{2} \mathrm{Si}$ intermetallic phase was observed, which indicated that the $\beta$ $\mathrm{Mg}_{2} \mathrm{Si}$ phase was well dissolved into the $\alpha$-Al matrix after the solution treatment. The well solid solution of $\beta-\mathrm{Mg}_{2} \mathrm{Si}$ phase could ensure the precipitation of nanoscale strengthening precipitates in the $\alpha$-Al matrix after ageing treatment, which contributes to the strengthening of the alloys after T6 heat treatment. With the increase in $\mathrm{Si}$, the volume fraction of spheroidised Si phase increases, for the condition refined by both Al5Ti1B and Al3Ti3B.

Figure 7a-d presents the bright-field TEM micrographs showing the $\beta^{\prime \prime}$ strengthening precipitate in the $\mathrm{Al}-x \mathrm{Si}-0.45 \mathrm{Mg}$ alloys with $6.5 \mathrm{wt} \% \mathrm{Si}, 7.5 \mathrm{wt} \% \mathrm{Si}$, $8.5 \mathrm{wt} \% \mathrm{Si}$ and $9.5 \mathrm{wt} \% \mathrm{Si}$, respectively, after T6 heat treatment. Embedded and lying $\beta^{\prime \prime}$ precipitates were found in the $\alpha$-Al matrix, which are the same precipitate since the $\beta^{\prime \prime}$ precipitate is needle-like. In Fig. 7 , the number density of the $\beta^{\prime \prime}$ precipitate increases slightly with the increase in Si content. Figure $8 \mathrm{a}$ shows the HRTEM image of the $\beta^{\prime \prime}$ precipitate embedded in the $(001)_{\mathrm{Al}}$ plane, and it clearly presents the unit cell of C-centred monoclinic structure with $a=1.52 \mathrm{~nm}$ and $c=0.67 \mathrm{~nm}$, which verifies that the embedded precipitate is $\beta^{\prime \prime}[27,28]$. Figure $8 \mathrm{~b}$ shows the corresponding FFT patterns of the rectangle area in Fig. $8 \mathrm{a}$, and it also confirms that the embedded precipitate is $\beta^{\prime \prime}$. Figure $8 \mathrm{c}$ shows the HRTEM image of the $\beta^{\prime \prime}$ precipitate lying on the $(001)_{\mathrm{Al}}$ plane, and Fig. 8d shows the corresponding FFT patterns of the rectangle area in Fig. $8 \mathrm{c}$, which verifies that the lying precipitate is $\beta^{\prime \prime}$, and the $\beta^{\prime \prime}$ precipitate is coherent with the $\alpha$-Al matrix along the $b$-axis. The needle-like $\beta^{\prime \prime}$ precipitate provides peak strengthening effect $[29,30]$, which indicates that the 

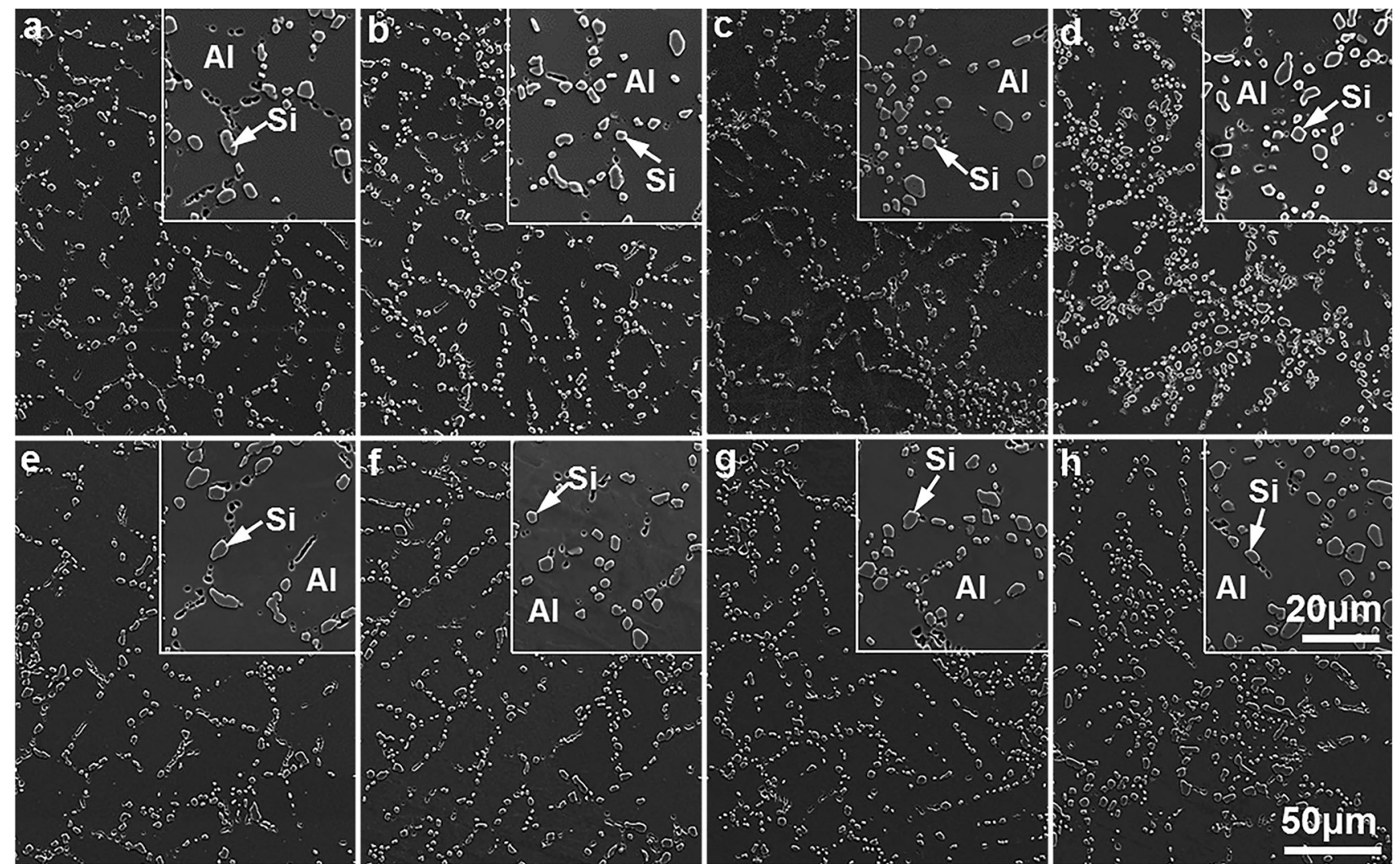

Figure 6 SEM micrographs showing the morphology of the T6 heat-treated $\mathrm{Al}-\chi \mathrm{Si}-0.45 \mathrm{Mg}$ alloys refined by a-d A15TilB and $\mathbf{e}-$ h Al3Ti3B with a, e $6.5 \mathrm{wt} \% \mathrm{Si}, \mathbf{b}, \mathbf{f} 7.5 \mathrm{wt} \% \mathrm{Si}, \mathbf{c}, \mathbf{g} 8.5 \mathrm{wt} \% \mathrm{Si}$ and $\mathbf{d}, \mathbf{h} 9.5 \mathrm{wt} \% \mathrm{Si}$.
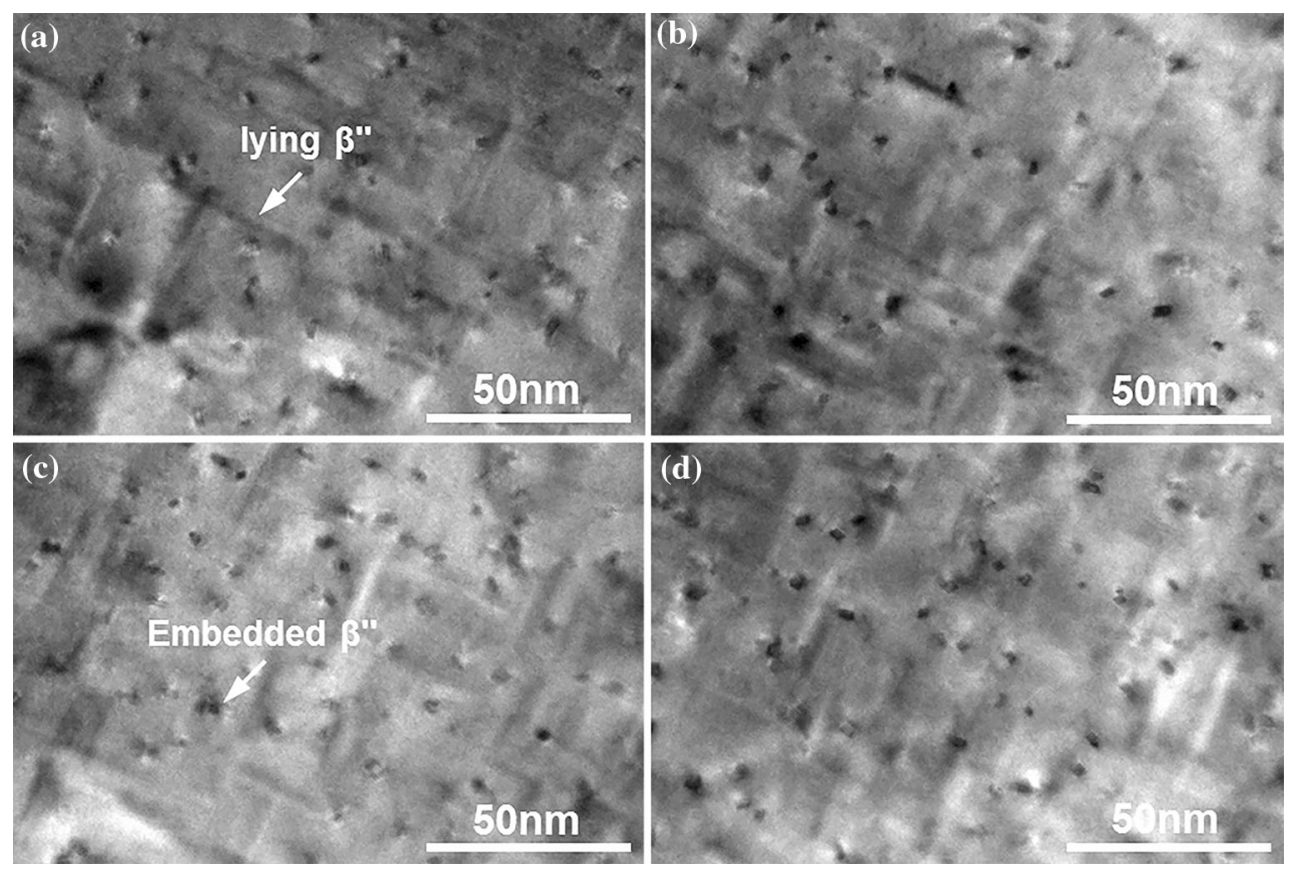

Figure 7 Bright-field TEM micrographs showing the $\beta^{\prime \prime}$ precipitate in the T6 heat-treated $\mathrm{Al}-x \mathrm{Si}-0.45 \mathrm{Mg}$ alloys: a $6.5 \mathrm{wt} \% \mathrm{Si}$, b $7.5 \mathrm{wt} \% \mathrm{Si}$, c $8.5 \mathrm{wt} \% \mathrm{Si}$ and $\mathbf{d} 9.5 \mathrm{wt} \% \mathrm{Si}$. 

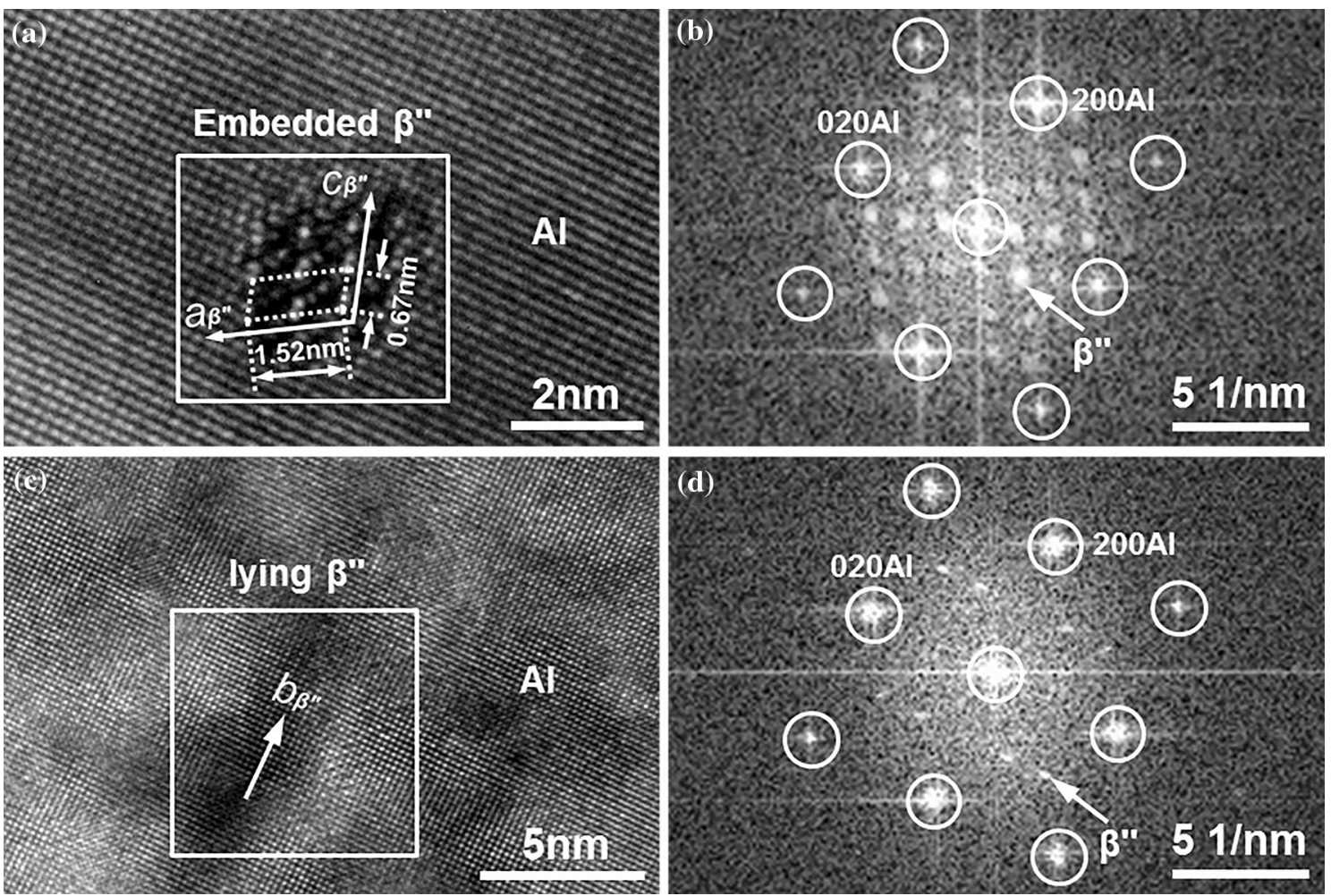

Figure 8 HRTEM micrographs taken along the $<001>\mathrm{Al}$ axis showing the $\beta^{\prime \prime}$ precipitate in the $\mathrm{T} 6$ heat-treated $\mathrm{Al}-x \mathrm{Si}-0.45 \mathrm{Mg}$ alloys, a HRTEM image of embedded $\beta^{\prime \prime}$ precipitate, $\mathbf{b}$ FFT pattern of $\mathbf{a}, \mathbf{c}$ HRTEM image of lying $\beta^{\prime \prime}$ precipitate and $\mathbf{d}$ FFT pattern of $\mathbf{c}$.

T6 heat-treated $\mathrm{Al}-x \mathrm{Si}-0.45 \mathrm{Mg}$ alloys are in the peak strengthening state.

\section{Mechanical properties after heat treatment}

Figure $9 \mathrm{a}, \mathrm{b}$ shows the tensile stress-strain curves and tensile properties of the Al5Ti1B-refined $\mathrm{Al}-x \mathrm{Si}-$ $0.45 \mathrm{Mg}$ alloys, after $\mathrm{T} 6$ heat treatment. Under the refinement of Al5Ti1B, with the increase in Si content from 6.5 to $7.5,8.5$ and $9.5 \mathrm{wt} \%$, the yield strength (YS) increases nearly linear from $294 \pm 2$ to $299 \pm 2$, $304 \pm 1$ and $309 \pm 2 \mathrm{MPa}$, and the tensile strength (UTS) increases from $336 \pm 7$ to $351 \pm 4,358 \pm 3$ and $363 \pm 4 \mathrm{MPa}$, while the elongation (El) first increases slightly from $3.5 \pm 0.8$ to $4.5 \pm 1.0 \%$, then increases significantly to $7.8 \pm 1.4 \%$, after decreases to $5.5 \pm 1.2 \%$. Figure $9 c$, d shows the tensile stressstrain curves and tensile properties of the Al3Ti3Brefined $\mathrm{Al}-x \mathrm{Si}-0.45 \mathrm{Mg}$ alloys, after $\mathrm{T} 6$ heat treatment. Under the refinement of Al3Ti3B, with the increase in Si content from 6.5 to $7.5,8.5$ and $9.5 \mathrm{wt} \%$, the YS also increases nearly linear from $300 \pm 1$ to $305 \pm 2$, $312 \pm 1$ and $317 \pm 2 \mathrm{MPa}$, and the UTS increases from $352 \pm 3$ to $360 \pm 3,367 \pm 3$ and $372 \pm 3 \mathrm{MPa}$, while the elongation increases from $6.1 \pm 1.1$ to $8.5 \pm 1.2,11.8 \pm 1.5$ and $12.1 \pm 1.6 \%$. The Al3Ti3Brefined alloys have both higher strength and ductility than the Al5Ti1B-refined alloys. The YS and UTS of the alloys increase with increasing $\mathrm{Si}$ content. The ductility shows inverted ' $\mathrm{V}$ '-shaped evolution with $\mathrm{Si}$ content and reaches the peak at $8.5 \mathrm{wt} \% \mathrm{Si}$ when refined by Al5Ti1B, while the ductility increases with Si content when refined by Al3Ti3B.

\section{Discussion}

\section{Si poisoning on microstructure under Al5Ti1B}

Figure 10a shows the XRD pattern of the Al5Ti1B master alloy used for refinement; $\mathrm{TiAl}_{3}$ and $\mathrm{TiB}_{2}$ particles were found coexisting in the master alloy, which is consistent with the report that the particles introduced into the melt through the addition of Al5Ti1B are the soluble $\mathrm{TiAl}_{3}$ and the insoluble $\mathrm{TiB}_{2}$ particles [12]. Si in the melt reacted with $\mathrm{Ti}$ to form Ti-Si compounds, and the $\mathrm{TiB}_{2}$ particles that act as 
Figure 9 a, c Tensile stressstrain curves and $\mathbf{b}, \mathbf{d}$ tensile properties of the $\mathrm{Al}-x \mathrm{Si}-$ $0.45 \mathrm{Mg}(x=6.5,7.5,8.5$, 9.5) alloys refined by $\mathbf{a}$, b Al5TilB and c, d Al3Ti3B after T6 heat treatment.


heterogeneous nucleation sites for primary $\alpha-\mathrm{Al}$ phase could be poisoned by Si by coating the surfaces with Ti-Si compounds [16, 17]. The detail poisoning mechanism of $\mathrm{Si}$ on $\mathrm{TiB}_{2}$ particles has been verified by experiment recently with $\mathrm{Al}-\mathrm{Si}-\mathrm{Ti}$ particles observed on the prism face of $\mathrm{TiB}_{2}$ [18]. The formation of Ti-Si compounds also consumes the Ti dissolved in the melt for grain growth restriction, and the solute Ti was reported hardly offering any grain growth restriction effect in $\mathrm{Al}-\mathrm{Si}$ alloys with a $\mathrm{Si}$ content up to $7 \mathrm{wt} \%$ [15]. With the increase in $\mathrm{Si}$ content from 6.5 to $9.5 \mathrm{wt} \%$, the poisoning effect of $\mathrm{Si}$ on the $\mathrm{TiB}_{2}$ particles increases, and the heterogeneous nucleation of primary $\alpha$-Al phase on $\mathrm{TiB}_{2}$ particles becomes more difficult, which results in the continuous significant coarsening of the primary $\alpha-\mathrm{Al}$ phase in the $\mathrm{Al}-x \mathrm{Si}-0.45 \mathrm{Mg}$ alloys refined by A15Ti1B. The increase in grain size coarsening rate in Al5Ti1B-refined $\mathrm{Al}-x \mathrm{Si}-0.45 \mathrm{Mg}$ alloys from $7.5 \mathrm{wt} \%$ Si might be attributed to the loss of grain growth restriction.

\section{Si poisoning and promotion on microstructure under Al3Ti3B}

Figure $10 \mathrm{~b}$ shows the XRD pattern of the Al3Ti3B master alloy used for refinement; $\mathrm{TiB}_{2}$ and $\mathrm{AlB}_{2}$ particles were found coexisting in the Al3Ti3B master alloy. It was reported that $\mathrm{AlB}_{2}$ alone without $\mathrm{Si}$ cannot effectively refine $\alpha-\mathrm{Al}$, while $\mathrm{AlB}_{2}$ with the
Figure 10 X-ray diffraction patterns of a A15Ti1B and b Al3Ti3B master alloys used for grain refinement.

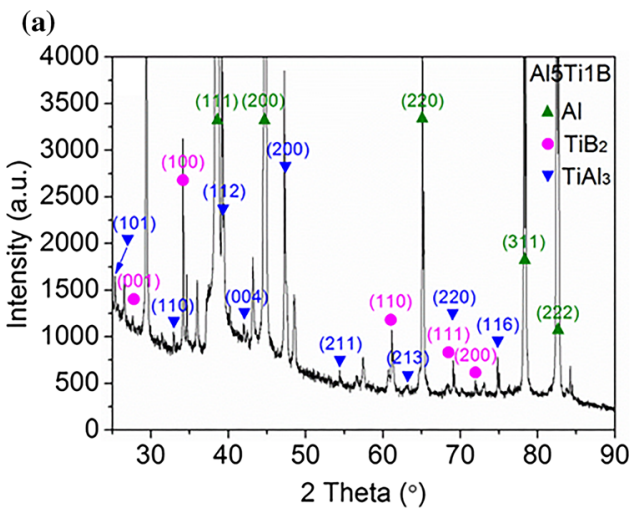

(b)

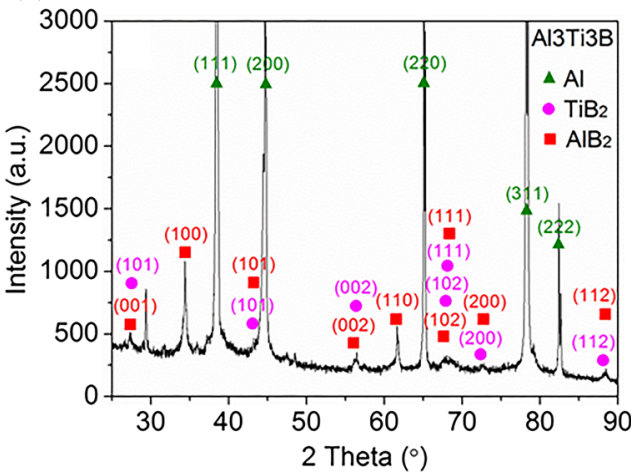


presence of Si could refine $\alpha$-Al efficiently, indicating that the solute Si may interfere with $\mathrm{AlB}_{2}$ to enhance its heterogeneous nucleating potential $[20,21]$. It was speculated that the formation of unstable $\mathrm{SiB}_{6}$ layer reduced the crystallographic mismatch between $\mathrm{AlB}_{2}$ and $\mathrm{Al}$, which enhanced the heterogeneous nucleating potency of $\mathrm{AlB}_{2}$ for primary $\alpha$-Al phase [22]. The formation of $\mathrm{SiB}_{6}$ layer is still not verified by experiments, but the promotion of heterogeneous nucleation potency of $\mathrm{AlB}_{2}$ by $\mathrm{Si}$ is the fact. There are two opposite effects of $\mathrm{Si}$ on the heterogeneous nucleation potency of $\mathrm{TiB}_{2}$ and $\mathrm{AlB}_{2}$ particles. With the increase in $\mathrm{Si}$, the $\mathrm{Si}$ poisoning of the heterogeneous nucleation on $\mathrm{TiB}_{2}$ particles increases, while the Si promotion of the heterogeneous nucleation on $\mathrm{AlB}_{2}$ particles increases. For the Al3Ti3B-refined $\mathrm{Al}-x \mathrm{Si}-$ $0.45 \mathrm{Mg}$ alloys, the poisoning of $\mathrm{Si}$ on $\mathrm{TiB}_{2}$ is not significant at $6.5 \mathrm{wt} \% \mathrm{Si}$, resulting in the fine primary $\alpha$ $\mathrm{Al}$ grain size of $215 \pm 30 \mu \mathrm{m}$; with the increase in $\mathrm{Si}$ content to $7.5 \mathrm{wt} \%$, the poisoning of $\mathrm{Si}$ on $\mathrm{TiB}_{2}$ is a little more significant than the promotion of $\mathrm{Si}$ on $\mathrm{AlB}_{2}$, which leads to the slight increase in primary $\alpha$ $\mathrm{Al}$ grain size to $265 \pm 35 \mu \mathrm{m}$; with the further increase in $\mathrm{Si}$ content to $8.5 \mathrm{wt} \%$, there is a balance between the poisoning of $\mathrm{Si}$ on $\mathrm{TiB}_{2}$ and the promotion of $\mathrm{Si}$ on $\mathrm{AlB}_{2}$, which maintains the primary $\alpha-\mathrm{Al}$ grain size; with the increase in Si content to $9.5 \mathrm{wt} \%$, the poisoning of $\mathrm{Si}$ on $\mathrm{TiB}_{2}$ is again a little more superior than the promotion of $\mathrm{Si}$ on $\mathrm{AlB}_{2}$, which causes the slight increase in primary $\alpha$-Al grain size to $315 \pm 25 \mu \mathrm{m}$. The sole nucleation site of $\mathrm{TiB}_{2}$ suffers from enhancing $\mathrm{Si}$ poisoning with increasing $\mathrm{Si}$ under the refinement of $\mathrm{Al} 5 \mathrm{Ti1B}$, while the $\mathrm{AlB}_{2}$ nucleation site benefits from continuous $\mathrm{Si}$ promotion with increasing $\mathrm{Si}$ besides the $\mathrm{Si}$ poisoning of $\mathrm{TiB}_{2}$ nucleation site under the refinement of Al3Ti3B, which results in the significant finer grain size of primary $\alpha$-Al and the slight coarsening of the primary $\alpha$-Al with increasing $\mathrm{Si}$ in the Al3Ti3B-refined alloys, comparing with the Al5Ti1B-refined alloys.

\section{Multiple effects of Si on mechanical properties}

\section{Effects on yield strength}

The strengthening mechanisms in aluminium alloys generally include secondary phase strengthening, solution strengthening, precipitate strengthening, grain size strengthening and strain strengthening. For the $\mathrm{T} 6$ heat-treated $\mathrm{Al}-x \mathrm{Si}-0.45 \mathrm{Mg}$ alloys, the yield strength is mainly controlled by the secondary phase strengthening of Si phase, the precipitate strengthening of $\beta^{\prime \prime}$ precipitation phase and the grain size strengthening of primary $\alpha$-Al phase. In Figs. 5 and 6 , the secondary eutectic Si phase in the as-cast $\mathrm{Al}-x \mathrm{Si}-$ $0.45 \mathrm{Mg}$ alloys was fully spheroidised after T6 heat treatment. So the volume fraction of the secondary $\mathrm{Si}$ phase in the as-cast alloys is the same as the volume fraction of the spheroidised Si phase in the T6 heattreated alloys, which can be used for the evaluation of the secondary phase strengthening in the T6 heattreated alloys. In Fig. 6 , the $\beta-\mathrm{Mg}_{2} \mathrm{Si}$ intermetallic phase was fully dissolved into the $\alpha$-Al matrix after the solution treatment. In Figs. 7 and 8, the dissolved $\beta-\mathrm{Mg}_{2} \mathrm{Si}$ phase precipitates in the form of $\beta^{\prime \prime}$ precipitate in the $\alpha$-Al matrix for the precipitation strengthening of the alloys after the ageing treatment. Thus, the ratio between the volume fraction of $\mathrm{Mg}_{2} \mathrm{Si}$ phase and $\alpha$-Al phase in the as-cast alloys is the same as the ratio between the volume fraction of $\beta^{\prime \prime}$ precipitate and primary $\alpha$-Al phase in the T6 heat-treated alloys, which can be used for the evaluation of the precipitate strengthening in the T6 heat-treated alloys. Figure 11 shows the evolution of the volume fraction of secondary Si phase and the ratio between volume fraction of $\beta-\mathrm{Mg}_{2} \mathrm{Si}$ phase and $\alpha$-Al phase with $\mathrm{Si}$ in the as-cast $\mathrm{Al}-x \mathrm{Si}-0.45 \mathrm{Mg}$ alloys, which were calculated by the multicomponent phase diagram calculation software Pandat. With the increase in $\mathrm{Si}$ content, the volume fraction of secondary $\mathrm{Si}$ phase increases linearly, and the ratio between the volume fraction of $\beta-\mathrm{Mg}_{2} \mathrm{Si}$ phase and $\alpha-\mathrm{Al}$ phase increases nearly linearly. Thus, the secondary phase strengthening of spheroidised $\mathrm{Si}$ phase and the

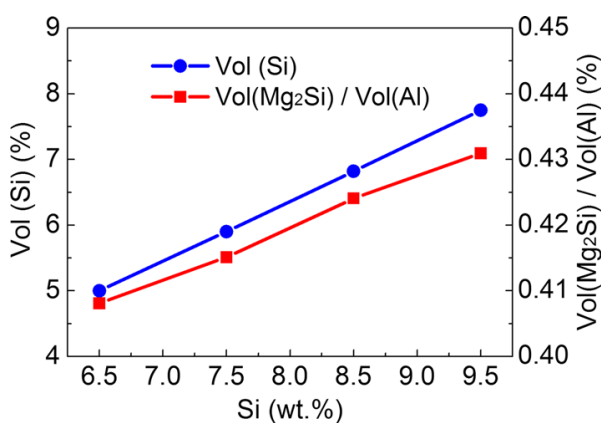

Figure 11 Volume fraction of eutectic Si phase and ratio between volume fraction of $\mathrm{Mg}_{2} \mathrm{Si}$ phase and primary $\alpha$-Al phase in as-cast Al- $x \mathrm{Si}-0.45 \mathrm{Mg}(x=6.5,7.5,8.5,9.5)$ alloys calculated by Pandat software. 
precipitate strengthening of $\beta^{\prime \prime}$ precipitation phase increase with increasing Si content in the T6 heattreated alloys.

In Figs. 2, 3 and 4, it can be expected that the grain size of primary $\alpha$-Al in the Al5Ti1B-refined alloys increases significantly with increasing $\mathrm{Si}$, and the grain size of primary $\alpha$-Al in the Al3Ti3B-refined alloys increases slightly with increasing $\mathrm{Si}$, after T6 heat treatment, since $\mathrm{T} 6$ heat treatment hardly has any effect on the grain size. According to the HallPetch relation, the grain size strengthening decreases with increasing grain size. The decrease in the grain size strengthening with increasing $\mathrm{Si}$ in the T6 heattreated alloys refined by Al3Ti3B is slighter than the alloys refined by Al5Ti1B. Under the refinement of both Al5Ti1B and Al3Ti3B, with the increase in Si, the increase in the secondary phase strengthening of spheroidised $\mathrm{Si}$ phase and the precipitate strengthening of $\beta^{\prime \prime}$ precipitation phase is superior to the decrease in grain size strengthening, which results in the increase in the yield strength with increasing $\mathrm{Si}$, as shown in Fig. 9.

\section{Effects on tensile strength and ductility}

The tensile strength and ductility of the T6 heattreated cast $\mathrm{Al}-\mathrm{Si}-\mathrm{Mg}$ alloys without porosity or other casting defects depend on the scale of the dendritic structure and the size and shape of the $\mathrm{Si}$ particles [31, 32]. The tensile strength and ductility of the T6 heat-treated cast Al-Si-Mg alloys with defects present are determined by the size and area fraction of defects on the fracture surface, rather than the bulk volume percentage of defects, and the tensile strength and ductility decrease monotonically with an increase in the area fraction of defects on the fracture surface $[33,34]$.

Figure 12a shows the evolution of the spiral flow length of the $\mathrm{Al}-x \mathrm{Si}-0.45 \mathrm{Mg}$ alloys versus $\mathrm{Si}$ content under the standard fluidity tests. The spiral flow length increases with the increase in Si content, which indicates that the fluidity of the $\mathrm{Al}-x \mathrm{Si}-0.45 \mathrm{Mg}$ alloys increases with increasing Si. Figure $12 b$ shows the volume percentage of porosity in the alloys refined by A15Ti1B and Al3Ti3B. Under the refinement of Al5Ti1B, with the increase in $\mathrm{Si}$ content from 6.5 to $7.5,8.5$ and $9.5 \mathrm{wt} \%$, the porosity percentage first decreases slightly from $0.22 \pm 0.02$ to $0.18 \pm 0.02 \%$, then decreases significantly to $0.11 \pm 0.01 \%$, after increases to $0.15 \pm 0.01 \%$. Under the refinement of
Al3Ti3B, with the increase in $\mathrm{Si}$ content from 6.5 to $7.5,8.5$ and $9.5 \mathrm{wt} \%$, the volume percentage of porosity first decreases slightly from $0.13 \pm 0.01$ to $0.1 \pm 0.01 \%$, then decreases significantly to $0.024 \pm 0.008 \%$, after decreases slightly to $0.017 \pm 0.006 \%$.

Figure 13a-d presents the SEM images showing the fracture morphology in the Al5Ti1B-refined Al$x \mathrm{Si}-0.45 \mathrm{Mg}$ alloys with $6.5 \mathrm{wt} \% \mathrm{Si}, 7.5 \mathrm{wt} \% \mathrm{Si}$, $8.5 \mathrm{wt} \% \mathrm{Si}$ and $9.5 \mathrm{wt} \% \mathrm{Si}$, respectively, after T6 heat treatment. Porosity defect was found on the fracture surface of the Al5Ti1B-refined alloys, and the insert in each figure shows the porosity morphology with higher magnification. With the increase in Si content from 6.5 to $7.5,8.5$ and $9.5 \mathrm{wt} \%$, the size and area fraction of porosity on the fracture surface first decrease, then reach the minimum at $8.5 \mathrm{wt} \% \mathrm{Si}$, after increase, which is consistent with the evolution of the porosity percentage with $\mathrm{Si}$ content shown in Fig. 12b. From the insert in each figure, the grain size in the A15Ti1B-refined alloys increases with increasing $\mathrm{Si}$, which is consistent with the microstructure and statistical results of grain size shown in Figs. 2 and 4 .

Figure 14a-d presents the SEM images showing the fracture morphology in the Al3Ti3B-refined Al$x \mathrm{Si}-0.45 \mathrm{Mg}$ alloys with $6.5 \mathrm{wt} \% \mathrm{Si}, 7.5 \mathrm{wt} \% \mathrm{Si}$, $8.5 \mathrm{wt} \% \mathrm{Si}$ and $9.5 \mathrm{wt} \% \mathrm{Si}$, separately, after T6 heat treatment. Porosity defect was found on the fracture surface of Al-6.5Si-0.45Mg and Al-7.5Si-0.45Mg alloys, and the inserts in Fig. 14a, b show the porosity morphology with higher magnification. With the increase in Si content from 6.5 to $7.5 \mathrm{wt} \%$, the size and area fraction of porosity on the fracture surface decrease. With the further increase in Si content to 8.5 and $9.5 \mathrm{wt} \%$, the porosity defect disappears from the fracture surface. The inserts in Fig. 14c, d show the enlarged fracture morphology, and the fracture comprises uniform distributed $\mathrm{Al}$ dimples and cracked $\mathrm{Si}$, which is very similar to the reported Al3Ti3B-refined Al9SiMg alloy [10]. The evolution of porosity on the fracture surface of the Al3Ti3B-refined alloys with $\mathrm{Si}$ is consistent with the evolution of the porosity percentage shown in Fig. 12b.

For the hypoeutectic Al-Si cast alloys, the porosity defect is mainly dependent on the solidification interval of the alloy, the fluidity of the liquid alloy and the grain size. Smaller solidification interval will result in lower tendency of porosity formation. Higher fluidity and smaller grain size will make the 
Figure 12 a Spiral flow length of $\mathrm{Al}-x \mathrm{Si}-0.45 \mathrm{Mg}$ alloys under the standard fluidity tests and $\mathbf{b}$ porosity percentage in the $\mathrm{Al}-x \mathrm{Si}-$ $0.45 \mathrm{Mg}$ alloys refined by Al5Ti1B and Al3Ti3B. (a)

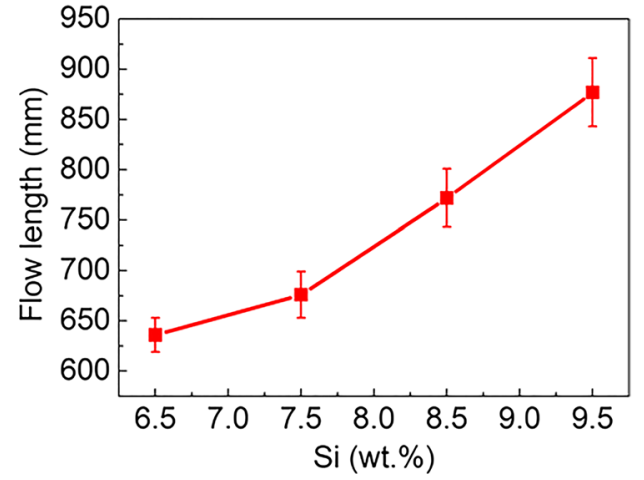

(b)

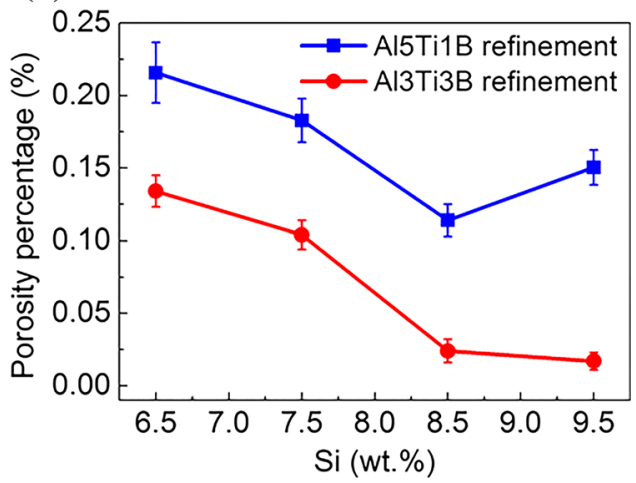

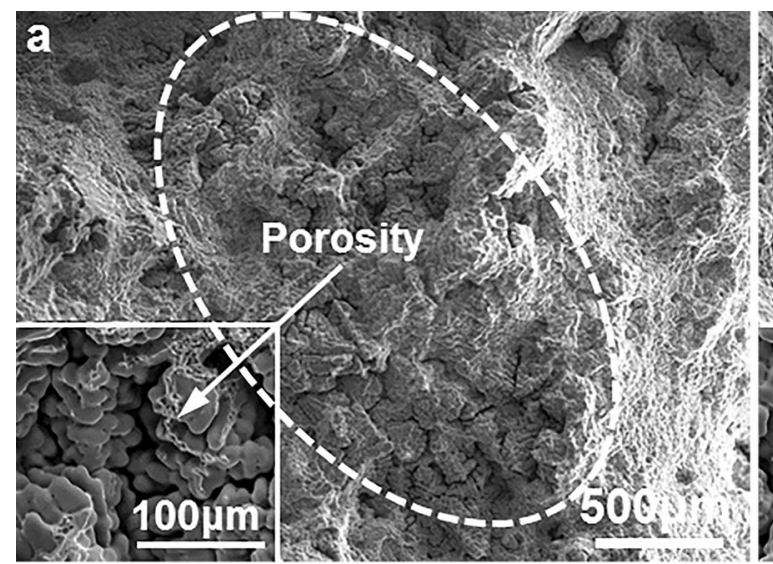
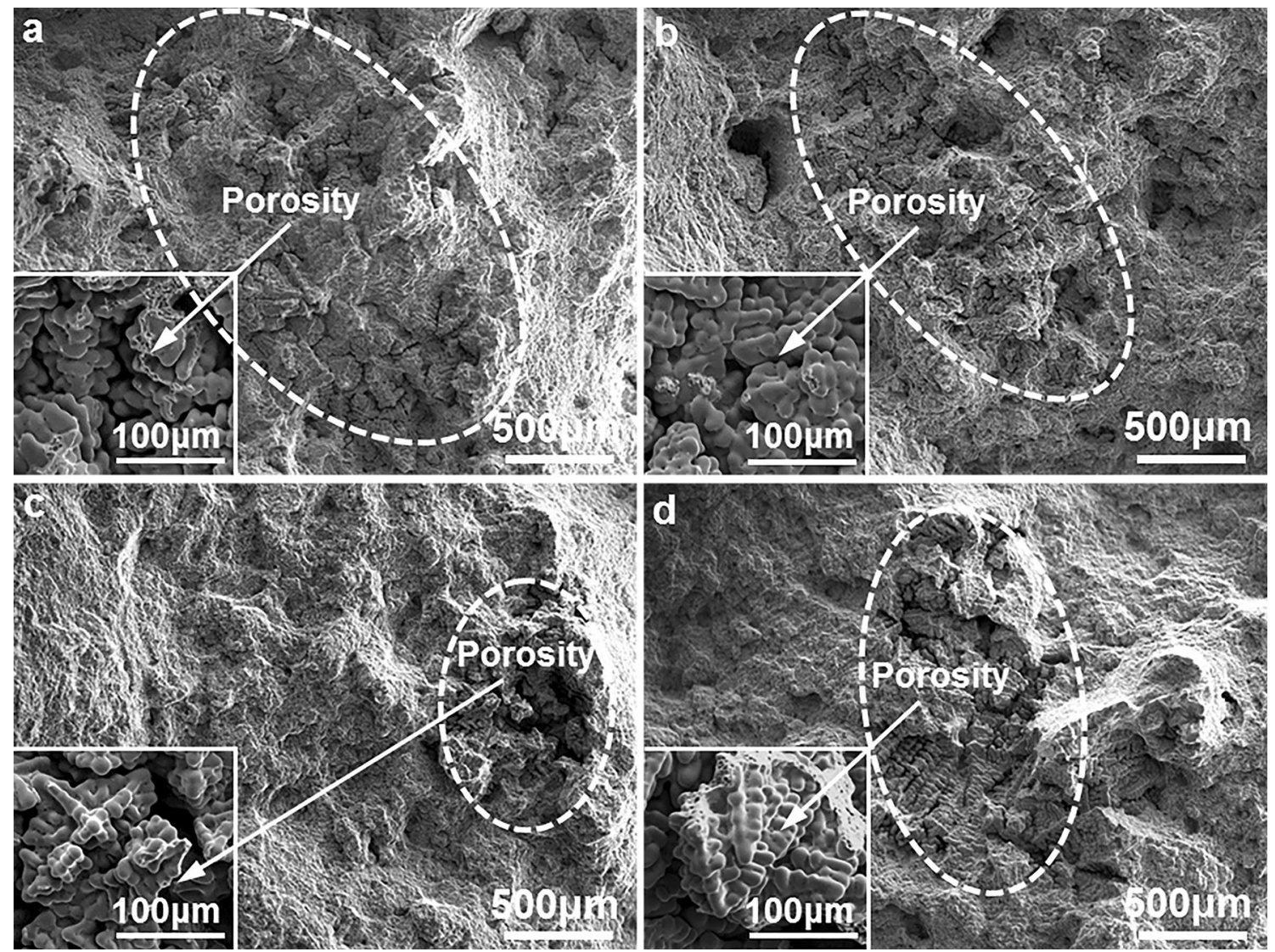

Figure $13 \mathrm{SEM}$ images showing fracture morphology in the T6 heat-treated $\mathrm{Al}-x \mathrm{Si}-0.45 \mathrm{Mg}$ alloys refined by $\mathrm{Al} 15 \mathrm{TilB}$ a $6.5 \mathrm{wt} \% \mathrm{Si}$, b $7.5 \mathrm{wt} \% \mathrm{Si}$, c $8.5 \mathrm{wt} \% \mathrm{Si}$ and $\mathbf{d} 9.5 \mathrm{wt} \% \mathrm{Si}$.

compensation of shrinkage easier and decrease the tendency of porosity formation. The solidification interval of the hypoeutectic $\mathrm{Al}-x \mathrm{Si}-0.45 \mathrm{Mg}$ alloys decreases with increasing $\mathrm{Si}$, which indicates that the tendency of porosity formation decreases with increasing $\mathrm{Si}$ from the viewpoint of solidification interval. In Fig. 12a, the fluidity of the liquid $\mathrm{Al}-x \mathrm{Si}-$ $0.45 \mathrm{Mg}$ alloys increases with increasing $\mathrm{Si}$, indicating that the tendency of porosity formation also decreases with increasing Si from the viewpoint of fluidity. According to Figs. 2 and 4, the grain size in the Al5Ti1B-refined alloys increases significantly with increasing Si due to the enhancing Si poisoning of $\mathrm{TiB}_{2}$ nucleation site, which indicates that the tendency of porosity formation in the Al5Ti1B-refined alloys increases with increasing $\mathrm{Si}$ from the viewpoint of grain size. In Figs. 3 and 4, the grain size in the Al3Ti3B-refined alloys increases slightly with 

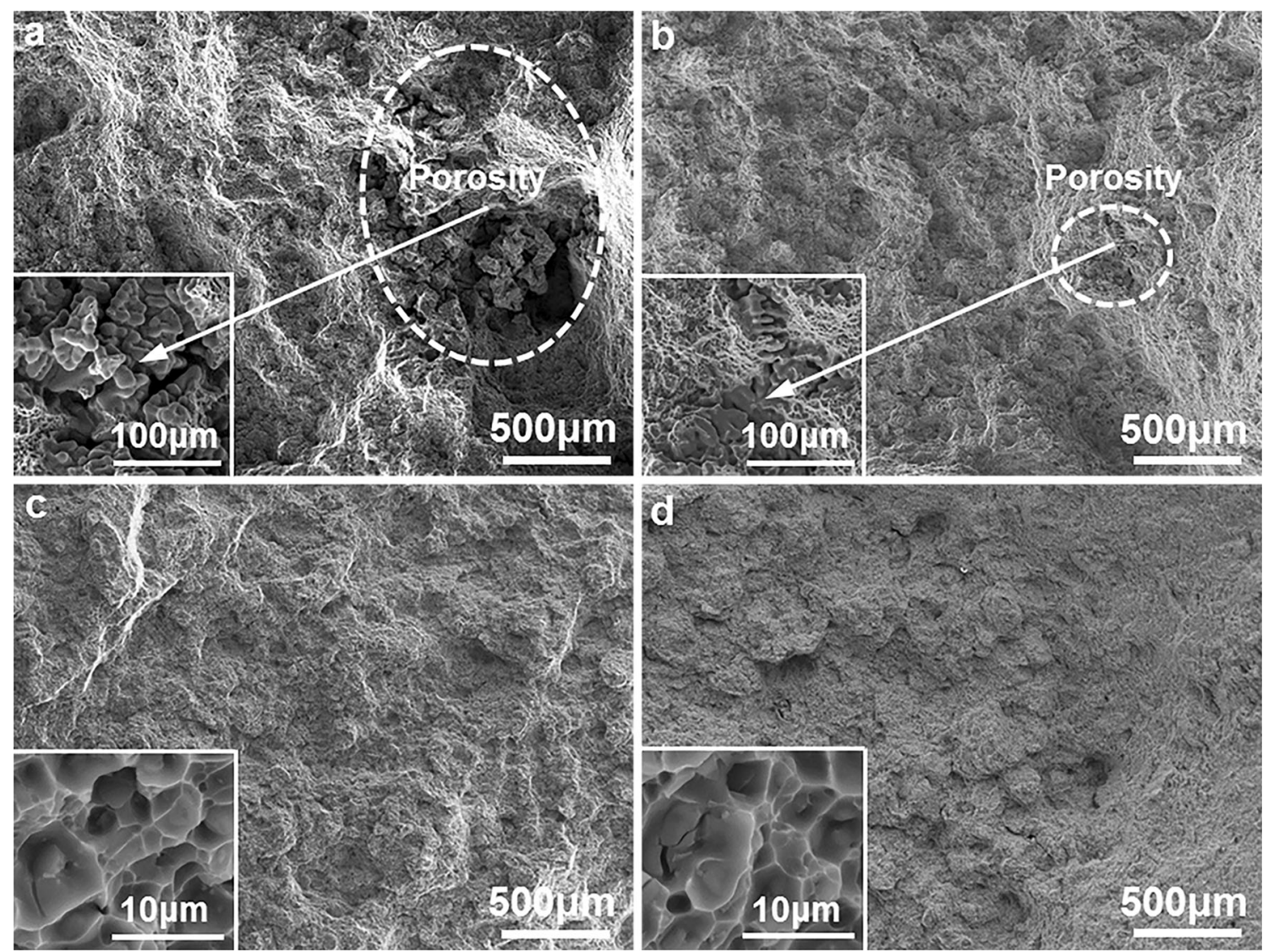

Figure $14 \mathrm{SEM}$ images showing fracture morphology in the T6 heat-treated $\mathrm{Al}-x \mathrm{Si}-0.45 \mathrm{Mg}$ alloys refined by $\mathrm{Al} 3 \mathrm{Ti3} \mathrm{B}$ a $6.5 \mathrm{wt} \% \mathrm{Si}$, b $7.5 \mathrm{wt} \% \mathrm{Si}$, c $8.5 \mathrm{wt} \% \mathrm{Si}$ and $\mathbf{d} 9.5 \mathrm{wt} \% \mathrm{Si}$.

increasing Si due to the enhancing Si promotion of $\mathrm{AlB}_{2}$ nucleation site besides $\mathrm{Si}$ poisoning, which indicates that the tendency of porosity formation in the Al3Ti3B-refined alloys increases slightly with increasing $\mathrm{Si}$ from the viewpoint of grain size.

For the Al5Ti1B-refined $\mathrm{Al}-x \mathrm{Si}-0.45 \mathrm{Mg}$ alloys, with the increase in $\mathrm{Si}$ content from 6.5 to $8.5 \mathrm{wt} \%$, the decrease in porosity formation by decreasing solidification interval and increasing fluidity is superior to the increase in porosity formation by increasing grain size, resulting in the decrease in size and area fraction of porosity on the fracture surface and the consequent increase in tensile strength and ductility till $8.5 \mathrm{wt} \%$ $\mathrm{Si}$; after the decrease in porosity formation by decreasing solidification interval and increasing fluidity is inferior to the increase in porosity formation by increasing grain size, resulting in the increase in size and area fraction of porosity on the fracture surface and the consequent decrease in ductility at $9.5 \mathrm{wt} \% \mathrm{Si}$. For the Al3Ti3B-refined $\mathrm{Al}-x \mathrm{Si}-0.45 \mathrm{Mg}$ alloys, with the increase in $\mathrm{Si}$ content from 6.5 to
$9.5 \mathrm{wt} \%$, the decrease in porosity formation by decreasing solidification interval and increasing fluidity is superior to the increase in porosity formation by slightly increasing grain size, which leads to the consecutive decrease in size and area fraction of porosity on the fracture surface and the consequent continuous increase in tensile strength and ductility.

\section{Conclusions}

The effects of Si poisoning and promotion on the microstructure and mechanical properties of hypoeutectic $\mathrm{Al}-x \mathrm{Si}-0.45 \mathrm{Mg}(x=6.5,7.5,8.5,9.5)$ cast alloys were investigated. The main conclusions are summarised as follows:

1. Al3Ti3B is superior to Al5Ti1B for the grain refinement of the $\mathrm{Al}-x \mathrm{Si}-0.45 \mathrm{Mg}(x=6.5,7.5,8.5$, 9.5) alloys. With the increase in $\mathrm{Si}, \mathrm{Si}$ poisoning on $\mathrm{TiB}_{2}$ results in the obvious coarsening of primary $\alpha-\mathrm{Al}$ in Al5Ti1B-refined alloys from 
$350 \pm 40$ to $400 \pm 50,475 \pm 50$ and $560 \pm 80 \mu \mathrm{m}$, and the competition between $\mathrm{Si}$ promotion on $\mathrm{AlB}_{2}$ and $\mathrm{Si}$ poisoning on $\mathrm{TiB}_{2}$ leads to the slight coarsening of primary $\alpha-\mathrm{Al}$ in Al3Ti3B-refined alloys from $215 \pm 30$ to $265 \pm 35,265 \pm 30$ and $315 \pm 25 \mu \mathrm{m}$.

2. The strength and ductility of Al3Ti3B-refined alloys are superior to that of the Al5Ti1B-refined alloys, after T6 heat treatment. With increasing $\mathrm{Si}$, the yield strength (YS) of A15Ti1B-refined alloys increases from $294 \pm 2$ to $299 \pm 2,304 \pm 1$ and $309 \pm 2 \mathrm{MPa}$, and the elongation first increases from $3.5 \pm 0.8$ to $4.5 \pm 1.0$ and $7.8 \pm 1.4 \%$, after decreases to $5.5 \pm 1.2 \%$, while the YS of the Al3Ti3B-refined alloys increases from $300 \pm 1$ to $305 \pm 2, \quad 312 \pm 1$ and $317 \pm 2 \mathrm{MPa}$, and the elongation increases from $6.1 \pm 1.1$ to $8.5 \pm 1.2$, $11.8 \pm 1.5$ and $12.1 \pm 1.6 \%$.

3 . The increase in the secondary phase and precipitation strengthening is superior to the decrease in grain size strengthening, which results in the increase in strength with increasing $\mathrm{Si}$. With the increase in $\mathrm{Si}$, the decrease in porosity formation by decreasing solidification interval and increasing fluidity is superior to the increase in porosity formation by slightly coarsening grain size, which leads to the continuous increase in ductility in the Al3Ti3B-refined alloys, while the competition between porosity decreasing and increasing factors leads to the inverted ' $\mathrm{V}$ 'shaped evolution of ductility in the Al5Ti1Brefined alloys.

\section{Acknowledgements}

Financial support from Innovate UK under project 131817 is gratefully acknowledged.

Open Access This article is distributed under the terms of the Creative Commons Attribution 4.0 International License (http://creativecommons.org/ licenses/by/4.0/), which permits unrestricted use, distribution, and reproduction in any medium, provided you give appropriate credit to the original author(s) and the source, provide a link to the Creative Commons license, and indicate if changes were made.

\section{References}

[1] Li PT, Liu SD, Zhang LL, Liu XF (2013) Grain refinement of A356 alloy by Al-Ti-B-C master alloy and its effect on mechanical properties. Mater Des 47:522-528

[2] Samuel E, Golbahar B, Samuel AM, Doty HW, Valtierra S, Samuel FH (2014) Effect of grain refiner on the tensile and impact properties of $\mathrm{Al}-\mathrm{Si}-\mathrm{Mg}$ cast alloys. Mater Des 56:468-479

[3] Birol Y (2017) Melt treatment of Al-Si foundry alloys with $\mathrm{B}$ and $\mathrm{Sr}$ additions. J Mater Sci 52:6856-6865. https://doi. org/10.1007/s10853-017-0923-y

[4] Dong XX, Mi GB, He LJ, Li PJ (2013) 3D simulation of plane induction electromagnetic pump for the supply of liquid Al-Si alloys during casting. J Mater Process Technol 213:1426-1432

[5] Dong XX, He LJ, Mi GB, Li PJ (2015) Two directional microstructure and effects of nanoscale dispersed Si particles on microhardness and tensile properties of AlSi7Mg meltspun alloy. J Alloy Compd 618:609-614

[6] Dong XX, He LJ, Huang XS, Li PJ (2015) Effect of electromagnetic transport process on the improvement of hydrogen porosity defect in A380 aluminum alloy. Int J Hydrog Energy 40:9287-9297

[7] Dong XX, He LJ, Huang XS, Li PJ (2015) Coupling analysis of the electromagnetic transport of liquid aluminum alloy during casting. J Mater Process Technol 222:197-205

[8] Dong XX, Huang XS, Liu LH, He LJ, Li PJ (2016) A liquid aluminum alloy electromagnetic transport process for high pressure die casting. J Mater Process Technol 234:217-227

[9] Wang YX, Guan RG, Hou DW et al (2017) The effects of eutectic silicon on grain refinement in an $\mathrm{Al}-\mathrm{Si}$ alloy processed by accumulative continuous extrusion forming. J Mater Sci 52:1137-1148. https://doi.org/10.1007/s10853016-0409-3

[10] Dong XX, Zhang YJ, Ji SX (2017) Enhancement of mechanical properties in high silicon gravity cast AlSi9Mg alloy refined by Al3Ti3B master alloy. Mater Sci Eng A 700:291-300

[11] Dong XX, Zhang YJ, Amirkhanlou S, Ji SX (2018) High performance gravity cast $\mathrm{A} 19 \mathrm{Si} 0.45 \mathrm{Mg} 0.4 \mathrm{Cu}$ alloy inoculated with $\mathrm{AlB}_{2}$ and $\mathrm{TiB}_{2}$. J Mater Process Technol 252:604-611

[12] Fan Z, Wang Y, Zhang Y, Qin T, Zhou XR, Thompson GE, Pennycook T, Hashimoto T (2015) Grain refining mechanism in the Al/Al-Ti-B system. Acta Mater 84:292-304

[13] Spittle JA, Sadli SB (1995) Effect of alloy variable on grain refinement of binary aluminium alloys with Al-Ti-B. Mater Sci Technol 11:533-537 
[14] Lee YC, Dahle AK, Stjohn DH, Hutt JEC (1999) The effect of grain refinement and silicon content on grain formation in hypoeutectic Al-Si alloys. Mater Sci Eng A 259:43-52

[15] Birol Y (2012) Effect of silicon content in grain refining hypoeutectic Al-Si foundry alloys with boron and titanium additions. Mater Sci Technol 28:385-389

[16] Mohanty PS, Gruzleski JE (1996) Grain refinement mechanisms of hypoeutectic Al-Si alloys. Acta Metall Mater 44:3749-3760

[17] Qiu D, Taylor JA, Zhang MX, Kelly PM (2007) A mechanism for the poisoning effect of silicon on the grain refinement of Al-Si alloys. Acta Mater 55:1447-1456

[18] Schumacher P (2017) Probing the heterogeneous nucleation interface of $\mathrm{TiB}_{2}$ in alloys by advanced electron microscopy. In: 6th Decennial international conference on solidification processing, Old Windsor, UK

[19] Wang T, Chen Z, Fu H, Xu J, Fu Y, Li T (2011) Grain refining potency of Al-B master alloy on pure aluminum. Scr Mater 64:1121-1124

[20] Kori SA, Murty BS, Chakraborty M (2000) Development of an efficient grain refiner for Al-7Si alloy and its modification with strontium. Mater Sci Eng A 283:94-104

[21] Birol Y (2012) Grain refinement of pure aluminium and Al7Si with Al-3B master alloy. Mater Sci Technol 28:363-367

[22] Chen ZN, Kang HJ, Fan GH et al (2016) Grain refinement of hypoeutectic Al-Si alloys with B. Acta Mater 120:168-178

[23] Birol Y (2012) Performance of AlTi5B1, AlTi3B3 and AlB3 master alloys in refining grain structure of aluminium foundry alloys. Mater Sci Technol 28:481-486

[24] Birol Y (2009) A novel Al-Ti-B alloy for grain refining AlSi foundry alloys. J Alloy Compd 486:219-222

[25] Tiryakioğlu M (2008) Si particle size and aspect ratio distributions in an $\mathrm{Al}-7 \% \mathrm{Si}-0.6 \% \mathrm{Mg}$ alloy during solution treatment. Mater Sci Eng A 473:1-6
[26] Xu C, Xiao WL, Zheng RX, Hanada S, Yamagata H, Ma CL (2015) The synergic effects of $\mathrm{Sc}$ and $\mathrm{Zr}$ on the microstructure and mechanical properties of $\mathrm{Al}-\mathrm{Si}-\mathrm{Mg}$ alloy. Mater Des 88:485-492

[27] Andersen SJ, Zandbergen HW, Jansen J, Traeholt C, Tundal U, Reiso O (1998) The crystal structure of the $\beta^{\prime \prime}$ phase in Al-Mg-Si alloys. Acta Mater 46:3283-3298

[28] Yang WC, Wang MP, Zhang RR, Zhang Q, Sheng XF (2010) The diffraction patterns from $\beta^{\prime \prime}$ precipitates in 12 orientations in Al-Mg-Si alloy. Scr Mater 62:705-708

[29] Yang WC, Huang LP, Zhang RR, Wang MP, Li Z, Jia YL, Lei RS, Sheng XF (2012) Electron microscopy studies of the age-hardening behaviors in 6005A alloy and microstructural characterizations of precipitates. J Alloy Compd 514:220-233

[30] Yang WC, Ji SX, Huang LP, Sheng XF, Zhou L, Wang MP (2014) Initial precipitation and hardening mechanism during non-isothermal aging in an $\mathrm{Al}-\mathrm{Mg}-\mathrm{Si}-\mathrm{Cu}$ 6005A alloy. Mater Charact 94:170-177

[31] Cáceres CH, Davidson CJ, Griffiths JR (1995) The deformation and fracture behaviour of an $\mathrm{Al}-\mathrm{Si}-\mathrm{Mg}$ casting alloy. Mater Sci Eng A 197:171-179

[32] Cáceres CH, Griffiths JR (1996) Damage by the cracking of silicon particles in an $\mathrm{Al}-7 \mathrm{Si}-0.4 \mathrm{Mg}$ casting alloy. Acta Mater 44:25-33

[33] Surappa MK, Blank EW, Jaquet JC (1986) Effect of macroporosity on the strength and ductility of cast $\mathrm{Al}-7 \mathrm{Si}-0.3 \mathrm{Mg}$ alloy. Scr Metall 20:1281-1286

[34] Cáceres CH, Selling BI (1996) Casting defects and the tensile properties of an Al-Si-Mg alloy. Mater Sci Eng A 220:109-116 